\title{
Medical schools in concert on research ethics
}

Steve Nadis, Boston

Back in May, officials at Harvard Medical School gingerly stepped back from a plan to relax the institute's conflict-of-interest policies, which are considered among the strictest in the United States.

At the time, they called for a national forum to establish more uniform standards of conduct for researchers at US academic medical centres (see Nature 405, 497; 2000). Last week, a closed meeting in Washington edged these standards a step closer to reality.

Organized by Harvard's dean of medicine, Joseph Martin, the meeting brought together representatives from eight of the ten largest medical schools in terms of funding from the National Institutes of Health (including Harvard, Yale, Johns Hopkins, and Washington University). Also present were high-profile leaders such as former National Institutes of Health director Harold Varmus, now president of the Memorial Sloan-Kettering Cancer Center in New York.

According to those who attended, the meeting focused on the conflicts of interest that investigators might face when their research offers the potential for personal gain. Recent studies, including one that appeared last week in the New England Journal of Medicine $(343,1621-1626 ; 2000)$, have shown a high degree of variation in the ethics

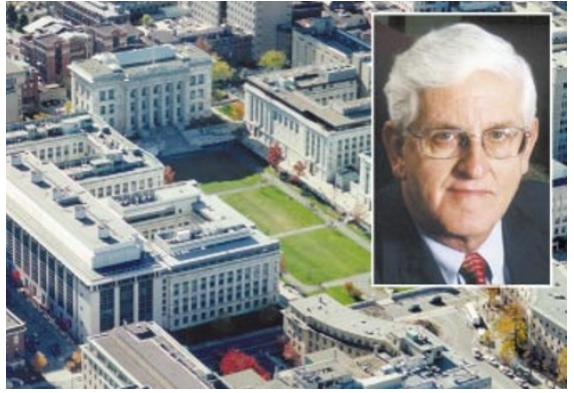

Raising the standard: Harvard's Joseph Martin wants a common policy for conflicts of interest.

policies of medical schools and teaching hospitals. Some have relatively strict rules, whereas others have no stated policies at all.

"This group agreed that it would be good for our community if there were less variability in these policies, while also encouraging the policies to be strengthened overall," says one attendee, David Korn, vice-president for research at the Association of American Medical Colleges (AAMC). "There was also agreement about the need for absolute and full disclosure, both internally and externally, regarding the possible financial interests of investigators," he adds.

The group agreed that every institution should have explicit conflict-of-interest policies, clear standards for disclosure of financial ties, and mechanisms for ensuring compliance with the guidelines. "These are broad principles, not detailed rules," Martin says. "We don't get into the nitty-gritty, as those details should be worked out by the individual institutions."

A draft statement of principles is now being circulated among meeting participants and could be released before the end of the year, says Dennis Kasper, dean of academic programmes at Harvard Medical School. "We don't represent anyone other than a small consortium of schools that met to talk about this, but we hope other schools will consider these principles."

Martin says that other institutions may be brought on board through the AAMC. The association has appointed a task force, chaired by William Danforth, former chancellor of Washington University, to review conflict-of-interest issues next year.

And although major medical schools are each likely to adhere to their own sets of conflict-of-interest rules, administrators believe that some commonality between these rules will help to discourage researchers from 'jumping ship' to more lenient institutions.

But Korn warns that there are more important issues at stake. "The critical thing is to maintain the public's confidence in medical research," he says.

\section{Xenotransplantation opponents take FDA to court}

\section{Paul Smaglik, Washington}

Opponents of xenotransplantation research have begun a lawsuit against the US Food and Drug Administration (FDA), demanding that more information be made public about experiments in which humans receive transplants of animal tissue.

The Campaign for Responsible

Transplantation, which filed the lawsuit, says adverse events from xenotransplantation have been reported in journals and at public meetings hosted by the FDA, but the agency has refused to release all the data from these trials. An FDA spokesperson declined to comment on the lawsuit.

The campaign group compares the work's secrecy to that which surrounded gene therapy until the death of a patient, Jesse Gelsinger, during clinical trials at the University of Pennsylvania last year. Alix Fano, director of the group, says that it wants xenotransplantation research to be as open as gene-therapy trials now are. "This is a new form of biotech - it's akin to the gene-therapy trials where a lot of side effects went unreported," she says.

Fano estimates that there are around a dozen xenotransplantation trials under way in the United States. The precise number is unknown, she says, because the FDA does not disclose it. The trials began more than 30 years ago, with about 12 transplants of chimpanzee organs. More recent experiments have studied the transplantation of cells, rather than complete organs.

LeRoy Walters, director of the Kennedy Institute of Ethics at Georgetown University in Washington DC, supports the idea that data from medical research should be more freely available. "I would like to see a public registry of all clinical trials across the board," he says.

The lawsuit reflects the tension between the industrial sponsors of research, who want to keep the results of clinical trials private, and some public-health advocates, who want more openness. That tension increased last autumn following Gelsinger's death, which set in motion a chain of events that resulted in a publicly accessible database of gene-therapy clinical trials.

Drug companies say that the release of

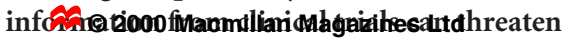
their competitiveness. But campaigners and

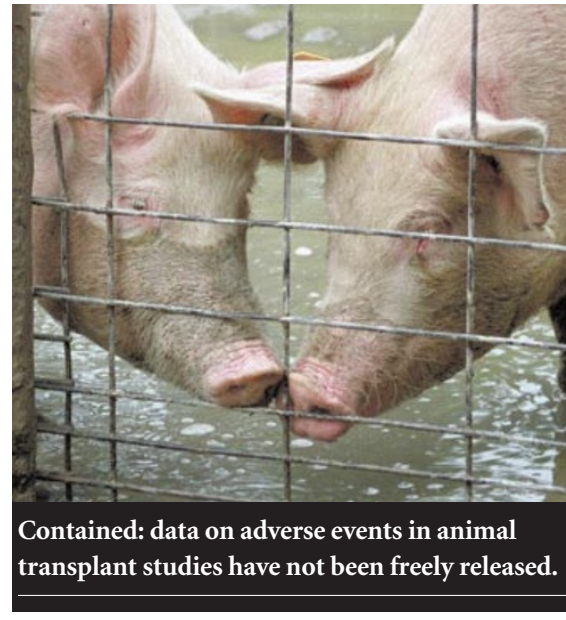

bioethicists argue that both gene therapy and xenotransplantation differ so much from conventional medicine that more transparency is needed.

Gene therapy, they say, runs the risk of germline gene transfer, where genetic changes are passed unintentionally to the patient's children. With xenotransplantation, critics worry that retroviruses might pass from animals to humans. 